\title{
Comparison of Performance Assessment Indicators for Evaluation of Irrigation Scheme Performances in Sri Lanka
}

\section{S.M.D.L.K. De Alwis and N.T.S. Wijesekara}

\begin{abstract}
Managing resources in a major irrigation scheme needs more attention on system performance in order to get optimum production out of available resources. In Sri Lanka most major irrigation schemes are managed using conventional management strategies together with the traditional experiences of farmers and managers. In most instances a systematic approach for observation or resource use and management are not adhered to either by scheme managers or by farmers. It is often observed that this results in low productivity. As such there is a need to evaluate irrigation scheme performance using suitable performance indicators in order to identify shortcomings and to find out solutions for increasing the productivity of such schemes. Since there are many factors affecting productivity of an irrigation scheme, most relevant factors should be identified in order to ascertain the most relevant data, minimum time, money, and expert services are spent. It is commonly believed that the present way of data collection by the majority for scheme evaluations do not serve the purpose since they are not designed for Sri Lanka's national needs. The present work is towards the development of a suitable performance assessment program for irrigation schemes in Sri Lanka considering water use efficiency, irrigation practices and land productivity. A critical comparison and review of available indicators were done considering the adequacy to monitor service delivery, productivity and agricultural economics and financing on irrigation system sustainability. One new indicator for water service delivery reflecting the effect of actual rainfall received was identified in this study along with two new indicators as Government Involvement and Beneficiary Involvement. This is proposed to monitor system sustenance which is a very important issue in the light of recent state policy of handing over of irrigation schemes to farmers. The present work after a systematic evaluation identified eleven suitable indicators for system performance measurement that would require minimum efforts on additional data collection and mobilising of fresh resources.
\end{abstract}

Key words: Water, Irrigation, Performance Indicators, Sri Lanka, Policy, Farmer, Beneficiary,

\section{Introduction}

In Sri Lanka, irrigated agriculture with a $28 \%$ share is the major user of surface water resources [1] (ID 2003). Irrigated agriculture accounts for about $96 \%$ of withdrawals of water from the surface. Out of a total irrigated area of 642,000 ha in 1991, the dry zone lands had been given irrigation water to the area of approximately $85 \%$ of the total annual irrigated area [2] (Amarasinghe, Mutuwatte and Sakthivadivel 1999). Since the livelihood of majority of dry zone community is agriculture, it is very important to efficiently and effectively use water for improving their living standards. Proper management of land, water, and agricultural inputs along with efficient operation and maintenance of irrigation systems are prerequisites for achieving optimum yield from the agricultural lands.

In the year 2000, national annual average yield had been reported as 3.7 MT/Ha while the target had been to reach a potential national average yield of 4.1MT/Ha for the year 2005 [3] (Dhanapala 2000).
The actual yield values for the year 2005 had been observed as $3.96 \mathrm{MT} / \mathrm{Ha}$ while in year 2008 this value had reached $4.18 \mathrm{MT} / \mathrm{Ha}$ [4] (internet http://www.statistics.gov.lk) In this context it is very important for irrigation stakeholders to carryout evaluation of irrigation scheme performances so that there is potential to effect timely and appropriate measures. Presently performance indicators in use measure productivity of water corresponding to the irrigated land area by computing the water duty in Acft/Ac, seasonal grain yield in MT/Ha and the contribution of district level paddy production or the average yield in MT/Ha [1] (ID 2003).

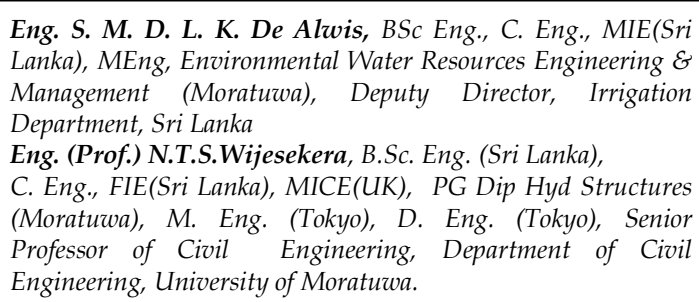


It has been noted that water duty values at the end of the season provide the overall water adequate information about the adequacy, reliability and timeliness of operations. Average yield which provides average productivity per unit area does not reflect the reasons for such yields. Literature indicated that most agriculture production indicators enable assessment of the performance of a season in terms of a selected criterion with respect to benchmark values. However scheme level benchmark values were not available at the Department of Agriculture except district level yield forecasts. In order to assess the Agriculture Economics \& Financing, status of the irrigated agriculture sector, the most common indicator used in Sri Lanka is 'Profit' which usually presents the national level performance using district level values [5] DOA(2005).

There are a large number of indicators presented in the literature together with those already in use enabling an irrigation manager to identify the effectiveness and efficiency of land and water resource usage ([1] ID 2003, [6] Bos Burton and Molden 2005, [7] Malano and Burton 2001). [8] Murray-Rust and Snellen (1993) carrying out an irrigation system case study including four schemes from Sri Lanka has indicated that lack of systematic measurement of performance, minimum concern about long term sustainability and poor consideration of institutional and resource condition are key factors that need to be addressed in the performance assessment of irrigated agriculture. [6] BOS, Burton, and Molden (2005) in their guideline very clearly indicate that the assessment of performance assessment procedure would vary depending on the purpose of the assessment and the type of scheme. In almost all irrigation schemes there are several indicators computed resulting from a vast data collection effort. However there are no supporting literatures or case studies to guide a scheme manager about the best indicators that could be used with either already collected data or with a minimum additional data collection effort. Therefore it is very important to carefully evaluate these indicators for the identification of the optimum effective management of the spatial units starting from irrigation scheme as operational units.

Informal discussions had with irrigation managers and farmers revealed that some of the important questions that require answers are the identification of operational performance of irrigation scheme tracts, productivity of turnout areas, performance of irrigation practices and assessment of profitability. Accordingly it is necessary to identify information consumption of the area, do not provide

pertaining to three major categories as (i) service delivery, (ii) production (iii) economics \& financing.

In this backdrop, the objective of the present work is to carryout a comparison of most common irrigation performance indicators to identify the best for Sri Lanka in order to address water use efficiency, irrigation practices, land productivity and system sustenance etc., with respect to water, yield and income consideration of Irrigation Department and the Farmer Organisations who are the two major stakeholder groups in the irrigation sector.

In the present work extensive discussions were held with irrigation managers and farmer organisation representatives to capture performance assessment needs especially in a turnout area basis for productivity enhancement. They are water utilisation and service delivery, land utilization, effective use of rainfall for production, provision of engineering and agricultural inputs, government support, and strength of farmer organizations and the enhancement of farmer status. The literature survey for the present work identified eleven major documents describing and discussing performance indicators that are relevant to the study objectives and number of indicators were captured with a listing of an associated categorisation (Table 1).

\subsection{Methodology and Analysis}

\subsection{Literature Survey}

Performance assessment is the systematic observation, documentation and interpretation of the management of an irrigation and drainage system to ensure intended outputs and proper functioning ([6] Bos, Burton and Molden 2005). The three key stakeholder interactions that have been identified in the irrigated agricultural sector are between, i) Water Institutions and Farmer Organizations, ii) Farmer Organizations and the Government and iii) Water Institutions and the Government ([9] Bandara 2006). Performance optimization of irrigation schemes is commonly applied either through planning, management, or structural interventions to improve application, conveyance or economic efficiency ([10] Jayatillake 2000). 
Indicators identified from the selected major references were then classified according to the (i) Service Delivery in three sub categories as Water Delivery, Maintenance, and Duty, (ii) Agriculture Production and (iii) Agricultural Economics and Financing (Table 2) since the interest group discussions and the literature survey identified these classes as the most important. In a comprehensive study for two irrigation schemes in Sri Lanka to develop and introduce cost effective performance assessment using remote sensing data, [9] Bandara (2006) listed 16 most relevant performance indicators based on the operational activities and based on the resource utilization.

An initial screening of literature was done to capture suitable indicators considering importance of Turnout level monitoring, capability to compute either with presently collected data or with acceptable estimations from scheme level or guideline information. Special attention was given to minimize the cost of data collection and to avoid carrying out special measurements unless the stakeholders expressed a pressing need. Subsequent to a comparison of similarity and effectiveness of outputs when compared with other identified indicators, a total of 18 indicators as indicated were listed (Table 2) under three main categories.

Eight service delivery indicators contained 4 of Water Delivery, 2 each of maintenance and duty. Five indicators related to Agriculture Production represent the measurement of productivity. Another five indicators which quantify the crop resource utilisation in financial terms and economic considerations are chosen to represent the Economics and Financing group.

\subsection{Comparison of Indicators}

A comparison of the selected indicators was initially done with respect to a water delivery system, and then a broader evaluation was carried out to select appropriate indicators for the entire system. Descriptions and definitions pertaining to each indicator were studied in detail to capture the objective, the evaluation criteria, and other important features for a critical assessment.

In major irrigation schemes of Sri Lanka, the common practice is to finalize the Seasonal Operation Plan (SOP) at a gathering called 'Kanna' meeting. This is a very special meeting in terms of irrigated agriculture in the scheme. Attended by the representatives of Farmer Organizations(FO), officers of the Irrigation Department (ID), officers of line agencies and personnel from associated private sector agencies and chaired by the District Secretary, discussions are held and decisions are taken regarding the proposed cropping pattern, availability of water, water delivery time schedule, schedule of schememaintenance works, maintenance work responsibilities of ID and FO, availability of other inputs such as seeds, fertilizer, credit facilities targeting optimum productivity. At these scheme level meetings, water duty and yield are the only performance indicators which are normally discussed. Only a minimum attention is given to irrigation management activities while in a majority of cases, no effort is made to identify problems or to find short and long term solutions for prevailing issues. Therefore it is important that suitable indicators are selected through a critical evaluation in order to surface most important issues.

\subsubsection{Service Delivery Performance}

\subsubsection{Water Delivery}

A summary of key aspects pertaining to the selected water delivery indicators are in the Annex 1. Water delivery indicators attempt to reflect the effectiveness of delivering optimum water expected for crop growth. Each indicator was assessed through a study of the definition, description, nature of intervention and comments were made. Indicator comparison also considered the requirement of temporal and spatial monitoring requirements to achieve optimum outputs. All selected indicators provide similar results through a measure of supply relative to the demand. Hence delivery can be either by rainfall, irrigation or other inflows, indicators have attempted to ensure the accounting of effective rainfall during the identification of water expected for optimum crop growth.

\subsubsection{System Sustenance}

In the literature only two performance indicators which directly address system sustenance could be identified. A brief outline interpretation of the two indicators is given in the Annex 1. Estimation, availability and utilization of funds for irrigation system sustainability activities and their periodical achievements reflect the way an irrigation system had performed and would enable forecasting to assess performance during its service delivery period. Financial involvement 
for Maintenance, Operation and Management (MOM) in an irrigation scheme is generally taken to reflect the strength of Irrigation System sustenance. In major and medium irrigation schemes, the Government of Sri Lanka (GOSL) shoulders a large component of MOM fund requirements while Farmer Organizations too support several selected activities. Department of Irrigation of Sri Lanka as the implementing agency appointed by the government presently estimates the MOM costs at a fixed rate based only on the irrigable area. This often creates a mismatch between the budget provision and the actual requirements because market price of labour, material and transport significantly vary with the spatial location work even within a province. In Sri Lanka when identifying the Maintenance Budget Implementation Efficiency (MBIE) the assessments normally measure government expenses incurred for main and sub system maintenance against government fund allocation. Comparison of the two indicators show that while expressing the total MOM role without a separation between the involved parties, one indicates the per ha funding involvement while the other makes a comparison of allocation and the actual on an annual basis.

\subsubsection{Water Use}

Two indicators of water use could be identified from the literature and practice. Annex 1 provides a summary of the indicators detailed in the Table 1 and 2. In order to assess the water use efficiency on a per hectare of command area, Department of Irrigation, Sri Lanka use two indicators namely the irrigation duty and water duty respectively. Irrigation duty indicates the utilization of irrigation releases from head sluice to the command area. Water duty points to the water that was given to a soil plant system including effect of effective rainfall along with the irrigation water. Since the water use would be expected to assess efficiency in relation to irrigation efforts it is important to capture the irrigation duty of a particular scheme for comparison of irrigation efforts. The total water use with the inclusion of rainfall would also be an important factor but in an irrigation scheme there would be more value if the total water use could be related to the plants than simply to the land area. Therefore it is noted to capture this total water use by plant through an indicator within the water delivery system.

\subsubsection{Agricultural Production Performance}

The selected indicators (Table 1) attempt to capture the efficiency of production either in terms of land cultivated or command area, potential of the selected crop, volume of water and the fund generation per cultivation area. In order to measure Agricultural Production performance, relative yield and the output per unit command are the indicators which reflects the input output status in the specialized fields of agriculture and marketing but they are posing difficulties in collecting reliable data because of farmer reluctance to indicate actual income. The Yield provides a good measure by cultivated area only, cropping intensity reflects the efficient use of the total irrigable area, and Water use efficiency assesses the adequacy, equity and efficiency of water utilization.

\subsubsection{Performance of Agriculture Economics and Financing}

Selected indicators in this area attempt to capture the financial gains over the expenditure through various means. Out of the identified indicators (Table 1), the price ratio which provides details of price difference at two locations reflecting a farmer's profits and income, indicate difficulties in collecting reliable data. There is a difficulty in collecting data from reliable resources and therefore common practice is to perform periodical sample data collections which provide difficulties in spatial management. Cost recovery ratio and the $\mathrm{O} \&$ $\mathrm{M}$ Fraction which provide details of cost recovery and the proportion of MOM costs also indicate a significant increase of fresh data collection efforts since it is difficult to separate these components from the already available data. On the other hand the indicators, Resource Utilization which reflects the efficiency, and the Profit which reflects dependability of a scheme shows that unit level indications could be obtained with only a marginal effort enhancement.

\subsection{Discussion and Results}

\subsection{Service Delivery Performance}

It could be noted that the identified water delivery indicators attempt to capture the probable contribution of effective rainfall towards the crop water requirement when comparisons are made with the irrigation water delivered. However, it could be identified that none provide the opportunity to reflect the actual attempts taken by the technical inputs to account for actual rainfall and to reflect efforts taken at operation and planning. This can be achieved with a modification to the Delivery Performance Ratio ([6] Bos, Burton and Molden 
2005), which is incorporating the system concept and accounting for both irrigation and rain as a delivery service. Though the delivery of rain cannot be treated as part of service delivery, the attempts taken to account for rain during the operation of irrigation delivery can be grouped as a service. Therefore as shown below System Water Delivery Service is defined as the ratio of water actually received by the soil, plant system to volume of water targeted for the system for optimum crop growth i.e. the theoretically computed volume of water to be delivered to the system. shoulder system support activities. As this is a recent and important implementation, it is necessary to have close monitoring and meaningful evaluations. It is also necessary to identify a suitable performance indicator to capture the status of system sustenance because service delivery and agriculture production cannot be met without proper functioning of a particular irrigation system.

\begin{tabular}{|c|c|}
\hline \multirow{2}{*}{$\begin{array}{r}\text { System Water } \\
\text { Delivery Service } \\
(\text { SWDS })\end{array}$} & (Irrigation Water Delivered + Effective Rainfall + Other Inflow) \\
\hline & Intended Water Delivery to the Syste \\
\hline
\end{tabular}

The two indicators of system sustenance were picked due to their representation of very important characteristics. Since water duty in the group of water use indicators reflected a similarity in the above defined SWDS, only irrigation duty was selected.

\subsection{Agricultural Production, Economics and Financing}

In case of assessing agricultural production both cultivation land and command area assessment were considered very important together with the efficient use of water. Considering the data collection difficulties and also the objectives of scheme level monitoring, two indicators were chosen for capturing the productivity of enhancing the financial status.

\subsection{Institutional Development}

A macro look at the selections made from the indicators taken for comparison, it was noted that system sustenance aspects with respect to the Institutional Development require better representations. Farmer organizations (FOO) play a vital role in the irrigation scheme management because they are given the responsibility to manage all operations and maintenance activities of field canals and distributory canals in a Turnout area. FOO receive a financial allocation from the state for this work through an agreement signed with the Department of Irrigation. Previously the state was solely responsible for the system maintenance. According to the present policy the system component delivery is handed over to stakeholders in 1984, thereby requiring farmers to
Accordingly two indicators were developed to assess the Beneficiary Involvement (BI) and also the Government Involvement (GI). Beneficiary involvement is defined as the ratio of farmer organization contribution and the Government contribution to the FO as explained in the annex 1. This enables a comparison of the contributory components by the two major stakeholders spatially and with time enabling the identification of spatio-temporal consistency, attitudes, infrastructure status and sustenance in the light of system handing over.

$\begin{array}{r}\text { Beneficiary } \\ \text { Involvement } \\ (\mathrm{BI})\end{array}$
Government Contribution to Farmer Organization

The Government Involvement (GI) is to obtain an indication of contribution by the state towards the total MOM cost. There are four main components that constitute the total MOM cost. They are, the labour, management and sense of ownership input by Farmer Organizations, Expenditure borne by the Farmer Organization Funds, the Payment made to the Farmer Organizations by the Government through the irrigation Department and the Management Cost borne by the Irrigation Department.

\begin{tabular}{c}
$\begin{array}{c}\text { Government } \\
\text { Involvement } \\
(\mathrm{GI})\end{array}$ \\
\hline
\end{tabular}
latter two are the state contribution. This indicator would enable total system valuation concepts. 


\subsection{Indicator Coverage}

Based on the reasoning for acceptability to carryout performance monitoring in Sri Lankan irrigations schemes and especially with the author experience in the North Central Province, 11 indicators were selected as appropriate for irrigation scheme performance assessment. Adequacy of coverage of land and water resources, the aspect of resource that would be monitored and the data requirements to compute each indicator were listed and presented in the Table 3. Data needs to be indicated so that indicator values could be computed to a reasonable accuracy with the already available data and guidelines, though it may be necessary to strengthen the assessments at a Turnout level and at finer temporal resolutions. Assessment of indicator coverage on land and water as shown in the Table 3 shows that there are two and three indicators specifically on water and land respectively while the other six revealed and emphasised on cross linkages.

An evaluation of the assessment capability of the selected indicators with respect to irrigation scheme performance assessment objectives is shown in the Table 4. In this evaluation each performance indicator was first assessed in relation to each identified objective using a three class qualitative ranking representing Very High, High and Moderate. In order to obtain a numerical indication of the coverage, these qualitative classes were assigned values of 3, 2 and 1 for very high, high and moderate representations. Table 4 shows that except for two objectives all the other indicators were emphasising a single objective. It could also be noted that there were a sufficient cross connection representation enabling a mix of indicators providing details to easily identify focus regions for early action. The higher total numerical values for either the indicators or objectives indicated a representation of overall aspects and thereby hinting on the system healthiness. The lower values indicated more emphasis on specific target areas such as stakeholder involvement, engineering interventions, accounting for effective rainfall etc.

Selected indicators marks percentages that were computed by considering a possible maximum value that could be assigned. These percentages enable not only the identification of key parameters or the objectives with more emphasis, but also reflect that the specific objectives are reasonably represented in an overall manner having percentage values not less than $15 \%$.
The selected indicators did not contain the capability to capture the accounting of rainfall in irrigation water delivery, or the assessment of the provision of satisfactory engineering services, through a single indicator. This was not considered as a hindrance because these two aspects can be monitored reasonably through the others and also since they would have to be looked after when achieving other objectives. This was also due to the fact that the study attempts were to keep the number of indicators at a minimum.

\subsection{Conclusions}

1. A new indicator by the name of System Water Delivery Service-was defined to capture the accounting of actual rainfall received for optimum utilisation of water resources, ensuring a better delivery service.

2. A gap was identified in the available indicators to assess the institutional strength in irrigation schemes and this was filled by defining two new performance assessment indicators as Government Involvement and Beneficiary involvement reflecting government, irrigation department and framer organisation contributions.

3. Eleven indicators were identified as suitable for performance evaluation of irrigation schemes under four main sectors as Service delivery, Agricultural Production, Agriculture Economics and financing, and System Sustenance.

4. Four indicators for (i) service delivery, three for (ii) Production, two each for (iii) Economics and Financing and (iv) Institutional development were recognised as satisfactory for carrying out irrigation scheme performance assessment.

\section{References}

1. ID 2003 Irrigation Department, Water statistics handbook, Department of Irrigation, Colombo, Sri Lanka, 2003.

2. Amarasinghe, U.A., Mutuwatte, L., and Sakthivadivel, R., "Water Scarcity Variations within a Country: A Case Study of Sri Lanka", Research Report 32, International Water Management Institute, ISBN 92-9090-383-X, ISSN 1026-0862, Colombo, Sri Lanka,1999.

3. Dhanapala, M.P., "Bridging the Rice Yield Gap in Sri Lanka", Food and Agriculture Organization of the United Nations. Regional office for Asia and the Pacific, RAP publication 2000/16. 
4. Agriculture Statistics of Sri Lanka, Average Yield of 2008, http://www.statistic.gov.lk/agriculture, visited 16 th January 2011.

5. DOA (2005), "Cost of Cultivation of Agricultural Crops Maha 2004/2005", Publications of Socio Economics and Planning Centre (www.agridept.gov.lk), Department of Agriculture, Peradeniya, Sri Lanka.

6. BOS, M.G., Burton, M.A., Molden, D.J., "Irrigation and Drainage Performance Assessment", practical guide line. (ICTAD, CID, IWMT). Ch 3, 2005, pp. 26 86 and pp. $144-151$.

7. Malano, H., and Burton, M., "Guideline for Bench Marking Performance in the Irrigation and Drainage Sector", 2001

8. Murray-Rust, D.H. and Snellen, W.B., "Irrigation System Performance Assessment and Diagnosis". Joint IIMI/ILRI/IHEE publication. International Irrigation Management Institute, Colombo, Sri Lanka,1993.

9. Bandara, K.M.P.S., "Assessing Irrigation Performance by Using Remote Sensing". ch 3, pp. 27 - 41, ch 7, 2006, pp. 109 - 122

10. Jayathilake, H.M., "Rice in Major Irrigation Schemes Potential for Increased Cropping Intensities with Limiting Water Resources: Working paper Rice Congress". Audio Visual center of the Department of Agriculture, Peradeniya, Sri Lanka. ch 2, 2000, pp. 14 63.

11. Bos, M.G. and Nugteren, J., On Irrigation Efficiencies, $2^{\text {nd }}$ edn. ILRI publication No. 19. International Institute for Land Reclamation and Improvement (ILRI), Wageningen, The Netherlands,1974.

12. Molden, D.J., Sakthivadivel, R., Perry, C.J., de Fraiture, C. and Kloezen, W., "Indicators for Comparing Performance of Irrigated Agricultural Systems". Research Report 20. International Water Management Institute, Colombo, Sri Lanka,1999.

13. Rao, P.S., "Review of Selected Literature on Indicators of Irrigation Performance". IIMI Research paper. International Irrigation Management Institute, Colombo, Sri Lanka. ch 2, pp. 5 -10, ch 3, pp. $55-62$ and ch 4, 1993, pp. $63-64$.

14. Diskin Patrick, "Agriculture Productivity Indicator Measurement Guide". Food and Nutrition Technical Assistance, 1997, pp 01 - 41.

15. Wim, H., Klozenand \& Carlas Garces - Restrepo, "Assessing Irrigation Performance with comparative Indicators; The Case of Alto Rio Lerma Irrigation District, Mexico", Research Report 22 IWMI, 1998.

16. Karaa, K., Karam, F., Tarabey. N., “Attempt to Determine some Performance Indicators in the
QASMEH RAS - EL - AIN Irrigation scheme (Lebanon)", Technical Paper on Irrigation System Performance.

17. Ponrajah, A.J.P., Revised Edition, "Technical Guide Line for Irrigation Works, Irrigation Department, Sri Lanka". 1998, pp. 236 - 249.

18. Siriwardane, S.M.P., "Operational Performance Monitoring in System C of the Mahaweli Development Programme in Sri Lanka", 2001.

19. Ariyarathna, D.M., "Towards a New Agriculture Volume II Ministry of Agriculture and Land, Sri Lanka",1998.

20. Molden, D., "Accounting for Water Use and Productivity". SWIM paper I, International Irrigation Management Institute, Colombo, Sri Lanka,1997.

21. Strzepek, K., Molden, D., Galbraith, H., "Comprehensive Globle Assessment of Costs, Benefits and Future Directions of Irrigated Agriculture", 2001, Working paper 03. 
Table 1 - Selected Literature for Identifying Performance Indicators

\begin{tabular}{|c|c|c|}
\hline Reference & Category & $\begin{array}{l}\text { No. of } \\
\text { Indicators }\end{array}$ \\
\hline \multirow{5}{*}{$\begin{array}{l}\text { 01. Bos M.G., Burton M.A., Molden D.J., 2005, } \\
\text { Irrigation \& Drainage Performance Assessment } \\
\text { Practical Guideline, 2005. (ICID-CIID, IWMI), pp. } 143 \\
\text { - } 151 \text {. }\end{array}$} & $\begin{array}{l}\text { Water Delivery and } \\
\text { Utilization }\end{array}$ & 33 \\
\hline & Agriculture Production & 17 \\
\hline & $\begin{array}{l}\text { Agricultural Economics and } \\
\text { financing }\end{array}$ & 13 \\
\hline & Socio Economics & 10 \\
\hline & Environment & 5 \\
\hline \multirow{4}{*}{$\begin{array}{l}\text { 02. Malano H., Burton M., Guideline for } \\
\text { Benchmarking Performance in the Irrigation \& } \\
\text { Drainage Sector, 2001, }\end{array}$} & Service Delivery Performance & 8 \\
\hline & Financial & 7 \\
\hline & Productive Efficiency & 6 \\
\hline & Environmental Performance & 6 \\
\hline \multirow{3}{*}{$\begin{array}{l}\text { 03. Molden,D.J., Sakthivadivel, R., Perry, C.J., de } \\
\text { Fraiture, C. \& Kloezen, W., Indicators for Comparing } \\
\text { Performance of Irrigated Agriculture System, 1999, }\end{array}$} & $\begin{array}{l}\text { Irrigated } \\
\text { Outputs }\end{array}$ & 4 \\
\hline & Water Delivery & 3 \\
\hline & Financial Indicators & 6 \\
\hline \multirow{3}{*}{$\begin{array}{l}\text { 04. Rao, P.S., Review of Selected Literature on } \\
\text { Indicators of Irrigation Performance, 1993. (Research } \\
\text { Paper IIMI) }\end{array}$} & Water Delivery & 5 \\
\hline & Production & 3 \\
\hline & Agriculture Economics & 1 \\
\hline $\begin{array}{l}\text { 05. Patrick Diskin, Agriculture Productivity Indicator } \\
\text { Measurement Guide, } 1997 .\end{array}$ & Agriculture Productivity & 8 \\
\hline \multirow{5}{*}{$\begin{array}{l}\text { 06. Wim, H. Klozenand \& Carlas Garces - Restrepo, } \\
\text { Assessing Irrigation Performance with comparative } \\
\text { Indicators; The case of Alto Rio Lerma Irrigation } \\
\text { District, Mexico, 1998. (Research Report IWMI) }\end{array}$} & Water Delivery & 9 \\
\hline & Production & 4 \\
\hline & Financial & 2 \\
\hline & Agriculture & 4 \\
\hline & Environmental & 2 \\
\hline \multirow{3}{*}{$\begin{array}{l}\text { 07. Attempt to Determine some Performance } \\
\text { Indicators in the QASMEH RAS - EL - AIN Irrigation } \\
\text { Scheme (Lebanon) }\end{array}$} & Water Delivery Performance & 5 \\
\hline & Financial & 6 \\
\hline & Sustainability & 1 \\
\hline \multirow{2}{*}{$\begin{array}{l}\text { 08. Muray-Rust, D.H. \& Snellen, W.B., Irrigation } \\
\text { System Performance Assessment and diagnosis } \\
\text { (IIMI/ILRI/IHEE Publication), } 1993\end{array}$} & Operational Performance & \multirow[t]{2}{*}{$\begin{array}{c}\text { An overall } \\
\text { view }\end{array}$} \\
\hline & Strategic Performance & \\
\hline \multirow{2}{*}{$\begin{array}{l}\text { 9. Bandara, K.M.P.S., } 2006 \text { Assessing } \\
\text { Performance by using Remote Sensing } \\
\text { (Doctoral } \\
\text { Thesis) }\end{array}$} & Operational Performance & 10 \\
\hline & Resource Utilization & 6 \\
\hline \multirow{2}{*}{$\begin{array}{l}\text { 10. Ponrajah, A.J.P., Revised Edition, Technical Guide } \\
\text { Line for Irrigation Works, Irrigation Department, Sri } \\
\text { Lanka, 1988, }\end{array}$} & Water Delivery & 2 \\
\hline & Land Productivity & 1 \\
\hline \multirow{3}{*}{$\begin{array}{l}\text { 11. Siriwardane, S.M.P., } 2001 \text { Operational } \\
\text { Performance Monitoring in system C of the Mahaweli } \\
\text { Development programme in Sri Lanka, } 2001\end{array}$} & Water Delivery & 5 \\
\hline & Financial & 9 \\
\hline & Productivity & 8 \\
\hline
\end{tabular}


Table 2 - Indicator Classification - Service Delivery, Agriculture Production and Agricultural Economics and Financing

\begin{tabular}{|c|c|c|}
\hline $\begin{array}{l}\text { Performance } \\
\text { Indicators }\end{array}$ & Definition & $\begin{array}{c}\text { Evaluated Target } \\
\text { Criteria }\end{array}$ \\
\hline \multicolumn{3}{|c|}{ Service Delivery } \\
\hline \multicolumn{3}{|c|}{ Service Delivery - Water Delivery } \\
\hline $\begin{array}{l}\text { 1. Relative Water } \\
\text { Supply (RWS) }\end{array}$ & $\begin{array}{l}\text { Total Water Supply } \\
\text { Crop Water Demand }\end{array}$ & $\begin{array}{l}\text { Adequacy and } \\
\text { Equity }\end{array}$ \\
\hline \begin{tabular}{|l} 
2. Delivery \\
Performance Ratio
\end{tabular} & $\frac{\text { Actual Volume of Water }}{\text { Intended Volume of Water }}$ & $\begin{array}{l}\text { Adequacy and } \\
\text { Efficiency }\end{array}$ \\
\hline $\begin{array}{l}\text { 3. Overall Consumed } \\
\text { Ratio (OCR) }\end{array}$ & $\begin{array}{c}\text { (Potential Evpotranspiration - Effective Rainfall) } \\
\text { Water Volume Supplied to Command Area }\end{array}$ & Efficiency \\
\hline $\begin{array}{l}\text { 4. Water Use Efficiency } \\
\text { (WUE) }\end{array}$ & $\begin{array}{l}\text { Crop Water Demand } \\
\text { Total Water Supply }\end{array}$ & $\begin{array}{l}\text { Adequacy, Equity } \\
\text { and Efficiency }\end{array}$ \\
\hline \multicolumn{3}{|c|}{ Service Delivery - System Maintenance } \\
\hline $\begin{array}{l}\text { 5. Total MOM Cost per } \\
\text { Unit Area (Rs/ha) }\end{array}$ & $\begin{array}{c}\text { Total MOM Cost } \\
\text { Command Area Serviced by System }\end{array}$ & $\begin{array}{l}\text { Operational Viability, } \\
\text { Sustainability }\end{array}$ \\
\hline $\begin{array}{l}\text { 6. Maintenance Budget } \\
\text { Implementation } \\
\text { Efficiency } \\
\end{array}$ & $\begin{array}{c}\text { Annual Expenditure on Maintenance } \\
\text { Annual Money Allocated for Maintenance }\end{array}$ & Efficiency \\
\hline \multicolumn{3}{|c|}{ Service Delivery - Water Duty } \\
\hline 7. Irrigation Duty & $\begin{array}{c}\frac{\text { Volume Water Issued to Farms }}{\text { Area Cultivated }} \\
\end{array}$ & Utility \\
\hline $\begin{array}{l}\text { 8. Water Duty } \\
\text { (acft/acre) }\end{array}$ & $\begin{array}{c}\text { Volume Water Issued to Farms+ Effective Rainfall } \\
\text { Area Cultivated }\end{array}$ & $\begin{array}{c}\text { Equity and } \\
\text { Efficiency }\end{array}$ \\
\hline \multicolumn{3}{|c|}{ Production } \\
\hline 1. Yield (Mt/ha) & $\frac{\text { Crop Production }}{\text { Cropped Area }}$ & Productivity \\
\hline 2. Relative yield & $\begin{array}{c}\text { Actual Crop Yield } \\
\text { Potential Crop Yield }\end{array}$ & Production \\
\hline 3. Cropping Intensity & $\frac{\text { Area cultivated During the Year }}{\text { Command Area }}$ & Production \\
\hline $\begin{array}{l}\text { 4. Water use efficiency } \\
\left(\mathrm{Kg} / \mathrm{m}^{3}\right)\end{array}$ & $\begin{array}{c}\text { Crop Production } \\
\text { Volume of Water Supplied in Season }\end{array}$ & $\begin{array}{c}\text { Adequacy, equity } \\
\text { and efficiency }\end{array}$ \\
\hline $\begin{array}{l}\text { 5. Out put per unit } \\
\text { command }\end{array}$ & $\frac{\text { Value of Production }}{\text { Command Area }}$ & Productivity \\
\hline \multicolumn{3}{|c|}{ Economics and Financing } \\
\hline 1. Resource utilization & $\begin{array}{l}\text { Value of Production } \\
\text { Cost of Production }\end{array}$ & Efficiency \\
\hline 2. Cost recovery ratio & $\frac{\text { Gross Revenue Collected }}{\text { Total MOM Cost }}$ & Dependability \\
\hline 3. Profit (Rs/ha) & (Income - Expenditure) & profitability \\
\hline 4. O \& M fraction & $\frac{\text { Cost of O \& M }}{\text { Total Agency Budget }}$ & $\begin{array}{l}\text { Operational } \\
\text { viability }\end{array}$ \\
\hline 5. Price ratio & $\begin{array}{c}\text { Cost of O \& M } \\
\text { Total Agency Budget }\end{array}$ & $\begin{array}{c}\text { Profitability, } \\
\text { Farmer Economy }\end{array}$ \\
\hline
\end{tabular}




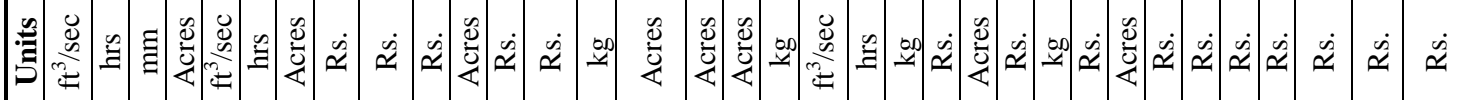

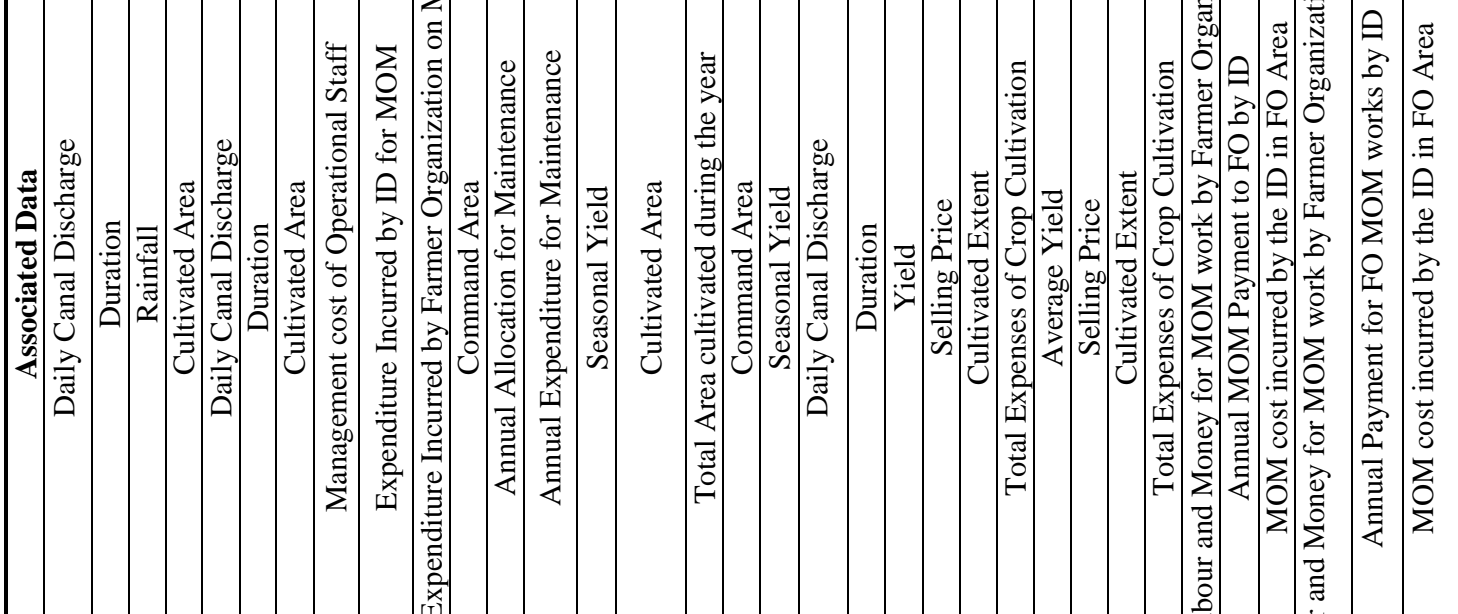

$\sum$

도ำ

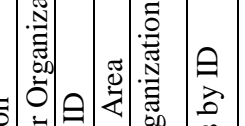

$+1$

|

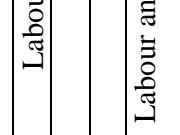

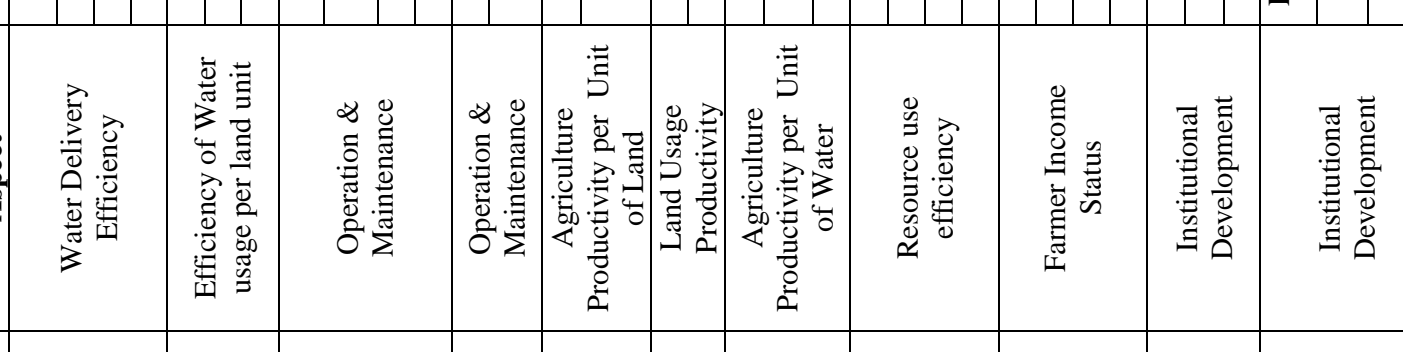

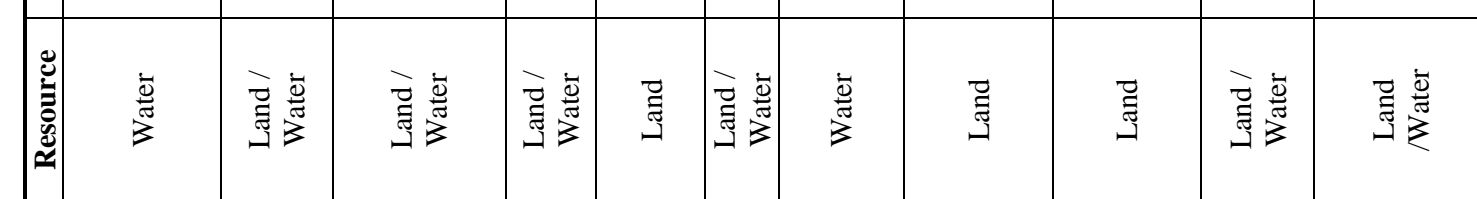

\begin{tabular}{|c|c|c|c|c|c|c|c|c|c|c|c|}
\hline$=$ & 冡。 & 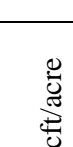 & $\frac{\pi}{5 \pi}$ & 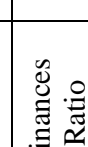 & $\stackrel{\pi}{5}$ & 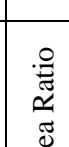 & 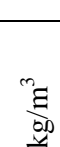 & $\frac{\pi}{5}$ & $\underset{5}{5}$ & ๘ึ & ฐु \\
\hline $\begin{aligned} 5 \\
5\end{aligned}$ & \multicolumn{4}{|c|}{1} & \multicolumn{3}{|c|}{ (1) } & \multicolumn{2}{|c|}{ sụ̣uru!g } & \multicolumn{2}{|c|}{ 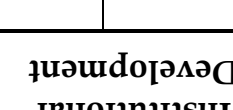 } \\
\hline
\end{tabular}

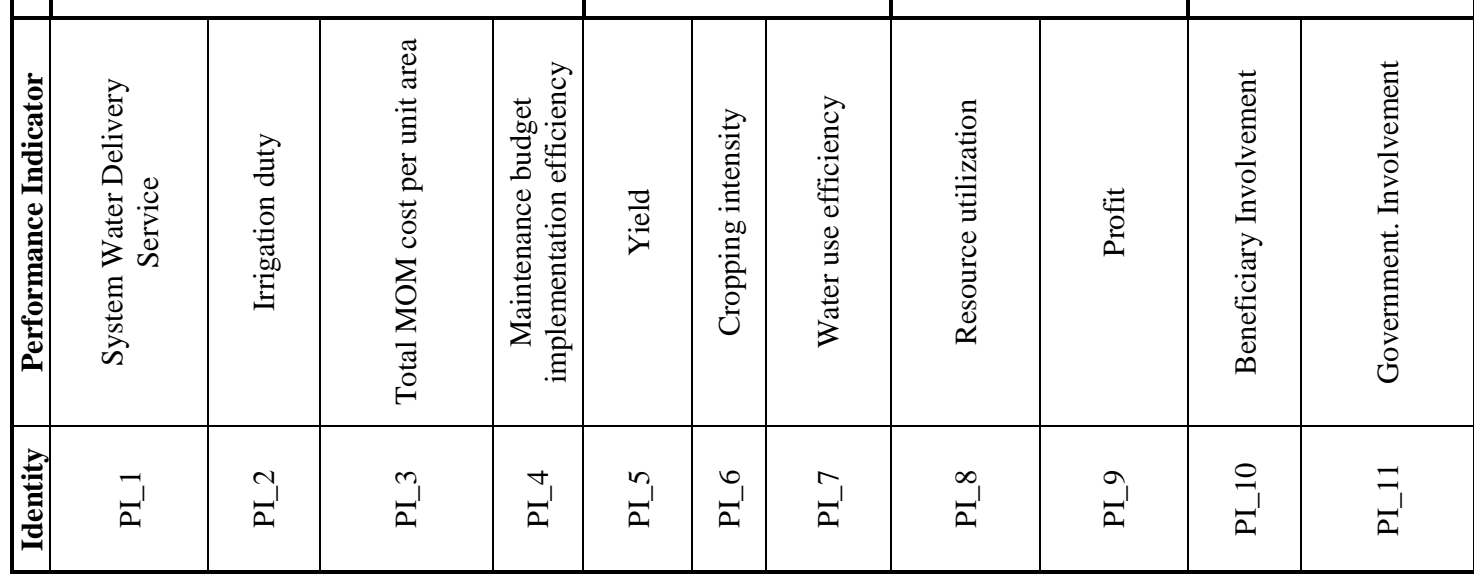


Table 4 - Assessment of Indicator Capability

\begin{tabular}{|c|c|c|c|c|c|c|c|c|c|c|c|c|c|c|}
\hline & & \multicolumn{11}{|c|}{ Selected Indicator } & \multirow[b]{2}{*}{ Total } & \multirow[b]{2}{*}{$\%$} \\
\hline & $\begin{array}{c}\text { Assessment } \\
\text { Objective }\end{array}$ & PI_1 & PI_2 & PI_3 & PI_4 & PI_5 & PI_6 & PI_7 & PI_8 & PI_9 & PI_10 & PI_11 & & \\
\hline 1 & $\begin{array}{l}\text { Irrigation Water } \\
\text { Utilisation }\end{array}$ & 1 & 3 & & & & 2 & 2 & 1 & 1 & & & 10 & $30 \%$ \\
\hline 2 & $\begin{array}{l}\text { Provision of Water } \\
\text { Delivery Service }\end{array}$ & 3 & 1 & & & 2 & 2 & 2 & & 1 & & & 11 & $33 \%$ \\
\hline 3 & Utilisation of Land & & 2 & & & 2 & 3 & & 1 & & & & 8 & $24 \%$ \\
\hline 4 & $\begin{array}{l}\text { Government Fund } \\
\text { Disbursement }\end{array}$ & & & & 3 & & & & & & 1 & 1 & 5 & $15 \%$ \\
\hline 5 & FO Contribution & & & 1 & 1 & & & & 2 & 1 & 3 & & 8 & $24 \%$ \\
\hline 6 & $\begin{array}{l}\text { Government } \\
\text { Contribution }\end{array}$ & & & 2 & 1 & & & & & & 2 & 3 & 8 & $24 \%$ \\
\hline 7 & $\begin{array}{l}\text { Provision of } \\
\text { Agricultural Input }\end{array}$ & & & & & 2 & & 3 & 2 & 2 & & & 9 & $27 \%$ \\
\hline 8 & $\begin{array}{l}\text { Farmer Economic and } \\
\text { Financial status }\end{array}$ & & & & & 3 & & & 3 & 3 & & & 9 & $27 \%$ \\
\hline 9 & $\begin{array}{l}\text { System Infrastructure } \\
\text { Maintenance }\end{array}$ & 1 & 1 & 3 & 2 & & & & 1 & & 1 & 2 & 11 & $33 \%$ \\
\hline 10 & Utilisation of Rainfall & 2 & 1 & & & 1 & 2 & & & 1 & & & 7 & $21 \%$ \\
\hline \multirow[t]{3}{*}{11} & \begin{tabular}{|l|} 
Provision of \\
Engineering Services
\end{tabular} & 2 & 1 & 2 & & & 2 & & 1 & 1 & & & 9 & $27 \%$ \\
\hline & $\begin{array}{l}\text { Total (Assigned } \\
\text { Marks) }\end{array}$ & 9 & 9 & 8 & 7 & 10 & 11 & 7 & 11 & 10 & 7 & 6 & & \\
\hline & $\%$ & $27 \%$ & $27 \%$ & $24 \%$ & $21 \%$ & $30 \%$ & $33 \%$ & $21 \%$ & $33 \%$ & $30 \%$ & $21 \%$ & $18 \%$ & & \\
\hline
\end{tabular}




\section{Annex 1 - Outline Description of Selected Indicators from the Literature}

\section{Performance Indicator Description}

1. Relative water supply is the measure of total volume of water delivered at turnout per unit of crop water demand. In this the total volume is the sum of surface diversion, net groundwater draft and the rainfall. Crop Water Demand is the total of potential crop evapotranspiration, deep percolation and seepage. RWS represents a combined effect on delivery performance and indicates whether the deliveries have met the crop water demand.

2. The Delivery Performance Ratio is the ratio of Actual Flow of water Delivered and the Field Irrigation Requirement which is the Intended flow to be delivered in this flow can be determined in two ways as flow rates and volume during a given period.

3. The Overall Consumed Ratio is computed as the ratio of irrigation requirement of a plant with respect to actual deliveries and other inflows to the soil plant system. OCR measures the water delivery efficiency indicating the adequacy of water for optimum growth of a crop.

4. Water Use Efficiency measures the Crop Water Demand of an area per unit of water supply to the crops.

5. Total MOM Cost per Unit Area is the total management, operation and maintenance cost per unit command area serviced by the system considering the costs that are borne by both Irrigation Department and Farmer Organisation involving the entire cost of providing irrigation and drainage service including capital expenditure, depreciation and renewal.

6. Maintenance Budget Implementation Efficiency is a relative measure of the actual and annual allocation of funds for system maintenance.

7. Irrigation Duty is defined as the volume of water issued to a unit farm area cultivated up to the point a crop reaches maturity.

8. Water duty relating the area irrigated and the quantity of water available for a crop to reach maturity is the sum of the volume of water issued to farms from the sluice of a tank and the effective rainfall in a particular season per unit cultivated area.

9. Yield defined as the crop production per unit crop area and usually measures the average yield in a command area in Mt/ha.

10.Cropping Intensity is the ratio of total area cultivated under both Yala and Maha season against the available total area of command.

11.Water use Efficiency is the ratio of weight of harvested yield and total volume of irrigation water supplied during a season and computed on an average basis for the command area in $\mathrm{kg} / \mathrm{m} 3$.

12. Output per unit command is the Ratio of value of production computed based on the farm gate price and the average harvested yield of actually cultivated command area measured in Rs./ha.

13. Resource utilization is defined as the ratio of value of production to cost of production. Value of production is the average yield at the local market price and cost of production is based on average expenses incurred for crop cultivation at scheme level and does not take the farmer family labour into account.

14. Cost Recovery Ratio is ratio of total revenue collected from water uses and total MOM cost incurred in the irrigation system.

15.Profit of a particular scheme is defined as the net earnings from a unit area of land and is calculated per season basis by subtracting the total expenditure incurred for the cultivation from the income from the crop cultivation.

16. Operation \& Maintenance Fraction is computed by dividing the sum cost of operation and maintenance by the total agency budget allocated for the scheme.

17.Price Ratio is the ratio of farm gate price and the nearest market price of crops.

18. Beneficiary Involvement is defined as the ratio of the value of farmer organization contribution for operation \& maintenance works and the value of government contribution to farmer organization to meet the operation \& maintenance expenses.

19. Government Involvement is the ratio of government contribution which is the total expenditure incurred by the government for management, operation and maintenance activities and total MOM cost which is the cost borne by both FO and government for the management, operation and maintenance activities. 